This is a so-called personal version (author's manuscript as accepted for publishing after the review process but prior to final layout and copy editing) of the article.

Hannele Kauppinen-Räisänen, Johanna Gummerus, Catharina von Koskull, Ake Finne, Anu Helkkula, Christian Kowalkowski, and Anne Rindell, (2014) "Am I worth it? Gifting myself with luxury", Journal of Fashion Marketing and Management, Vol. 18 Issue 2.

Readers are kindly asked to use the official publication in references.

\title{
Am I worth it? Gifting myself with luxury
}

\author{
Hannele Kauppinen-Räisänen ${ }^{\text {a, * }}$ \\ Johanna Gummerus ${ }^{\text {a }}$ \\ Catharina von Koskull ${ }^{\text {a }}$ \\ Åke Finne ${ }^{\mathrm{a}}$ \\ Anu Helkkula ${ }^{a}$ \\ Christian Kowalkowski ${ }^{\text {a }}$ \\ Anne Rindell ${ }^{\mathrm{a}}$
}

\footnotetext{
${ }^{a}$ Department of Marketing, CERS - Centre for Relationship Marketing and Service

Management, Hanken School of Economics, PO Box 479, FIN-00101 Helsinki, Finland

* Corresponding author: hannele.kauppinen-raisanen@hanken.fi
} 


\title{
Am I worth it? Gifting myself with luxury
}

\begin{abstract}
:
Purpose - Consumers gift themselves with luxury fashion brands, yet the motives for selfgifting are not well understood. Whereas traditionally, self-gifting is defined as self-orientated in nature, luxury brands are seen as social statements, and self-gifting of luxury fashion brands that combine these two controversial areas is an interesting research topic. This paper aims to address this issue by exploring the self-gifting behaviour of consumers, in particular focusing on the personal motives of gifting oneself with luxury fashion brands.

Design/methodology/approach - The study takes a multi-qualitative approach involving a small $(\mathrm{N}=19)$ but rich sample. Data collection and analysis were triangulated to reduce researcher biases.
\end{abstract}

Findings - The study provides key dimensions for understanding consumers' perceptions of luxury fashion brands and self-gifting motives (self- and socially-orientated). The findings reveal that reflections from others are part of the self-gifting phenomenon. It appeared that although self-orientated benefits and personally-orientated motives trigger the self-gifting act, the act of actually purchasing explicitly luxury brands for oneself as a gift may be triggered by other-orientated benefits and socially-orientated motives. The findings also imply that luxury holds a self-orientated aspect; luxury brands are not only purchased for sociallyorientated reasons but also for reasons related to oneself. In addition, the findings discuss the act of shopping, where the act can be perceived as a luxury experience and overrun the importance of the brand.

Practical implications - The findings provide insights to consumers' gifting behaviour that may be valuable for retailers and fashion marketers as they plan for marketing activities related to their customers' self-gifting.

Originality/value -Self-gifting represents a view of gifting that remains under-researched.

This study uncovers the motives for gifting oneself with luxury fashion brands, a further subarea in need for more investigation.

Keywords: household goods, gifts, luxury items, self-gifting

Article Classification: Research paper 


\section{Introduction}

The majority of a single item of expenditure of a household's income consists of unnecessary purchases. A recent report demonstrates that US consumers spend 15\% of their income on things that may be difficult to rationalise (McIntyre et al., 2011). The same report detected that one of the things consumers spent money on are gifts, accounting for $2.2 \%$ of households' annual income. Indeed gifting holds a significant monetary value, but it also encompasses various aspects: Gifting behaviour is embedded in our society (Ward and Tran, 2007). It is an act of bonding; individuals as relatives, friends and co-workers are acknowledged with gifts on various occasions such as birthdays (Clarke, 2008) and Christmas (Kemp et al., 2011). Yet, gifting is not limited to gifts given to others (Kemp et al., 2011), but refers also to gifts received from others and gifts purchased for oneself (Shiffman and Cohn, 2009; Ward and Tran, 2007); that is, self-gifting.

Gifting research has focused on interpersonal gifting, while self-gifting has received less scholarly attention (Davies et al. 2010; Ward and Tran, 2007). Although consumers prefer to purchase gifts for others, one aspect characterising current consumers' purchasing behaviour is the increasing engagement in gifting oneself (Turttle, 2012). Consumers are found to purchase up to ten gifts for personal use annually (Ward and Tran, 2007). One feature of these purchases is that consumers have a 'target' in mind like a reason for purchasing oneself a gift. Several such personal reasons have been detected as to reward oneself, to cheer oneself up and as therapy, due to holiday or one's birthday, to relieve stress, as an incentive to reach a personal goal, just to be nice to oneself and because one had extra money to spend (Mick and DeMoss 1990a, 1990b; 1992, Weisfeld-Spolter and Thakkar, 2012). The rare previous studies also show that some purchases are more prevalent as self-gifts than others, for example clothes, grocery, fast and slow food, music products and personal care services (Mick and DeMoss, 1992).

Another aspect characterising current purchasing behaviour is the increasing desire for luxury, such as luxury fashion brands. Indeed, the luxury fashion market is expanding globally and has an increasing economic impact even in emerging countries (Choo et al., 2012). Scholarly research and the fashion market commonly define luxury due to some specific characteristics of the luxury fashion brand, which distinguishes it from other brands, such as price, aesthetics, differentiation and quality, which all are on superior level (Jackson and Shaw, 2009; Okonkwo, 2007; Husic and Cicic, 2009). Research has detected various motives explaining consumers' desire for these luxury brands. On the one hand, internal motivations such as 
reward have been detected. On the other hand, research has detected external motivations explained by the perceived functional (quality and functionality), experiential (aesthetic, pleasure, experience, uniqueness, vanity, conformity) and symbolic (self-expression, conformity, social) benefits of acquiring luxury goods of which the symbolic dimension relates to the visibility and impression given to others (e.g. Berthon et al., 2009; Choo et al., 2012; Husic and Cicic, 2009; Park et al., 2008).

The previous discussion suggests that self-gifting is orientated to oneself in its nature (Davies et al., 2010), whereas purchases of luxury are described as being social statements (Amatulli and Guido, 2011), meaning their purchase is mainly other-orientated. Yet, past research suggests that self-gifting can be a behavioural act underlying purchases of luxury goods (Kim et al., 2011). This is an interesting issue that deserves scholarly attention as the motives for gifting oneself with luxury may differ from other, more mundane self-gifts. The review of the topic reveals that not only self-gifting (Ward and Tran, 2007), but in particular luxury selfgifting remains under-studied (Hung et al., 2011), and there is a need to further investigate this topic.

This study explores the phenomenon of gifting oneself with luxury fashion brands. It aims to shed light on three aspects of self-gifting with luxury fashion brands: 1) the act of self-gifting, 2) the nature of luxury fashion brands as perceived by consumers, 3) the consumers' motivations to self-gift with luxury fashion brands. The act of self-gifting is explored, since the broader purchase situation may have influence on consumer self-gifting outcomes (Luomala and Laaksonen, 1999). The nature of luxury fashion brands as perceived by customers is included since as Choo et al. (2012) stress, the understanding of the definitions of luxury itself and the luxury brand are at the core of understanding consumer behaviour related to luxury. Finally, the internal or personal motivations of self-gifting with luxury fashion brands are of specific interest because they have been overlooked so far (Kim et al., 2011). Here, the study attempts to reveal the potential conflict between self- and otherorientated motivations of self-gifting with luxury fashion brands.

By answering these aims, the study brings knowledge to self-gifting research. It also attempts to bring valuable insights into the field of luxury fashion brand research by exploring consumers' perceptions of the phenomenon of luxury fashion brands. Consumers' perceptions of luxury fashion brands and their motivations to gifting one-self with these brands are also essential for practitioners, such as fashion brand managers, to help them plan for services and offerings that allure consumers who self-gift. 
The rest of the paper is organised as follows. First, the consumption of luxury brands is discussed, followed by gifting/self-gifting and consumer self-gifting needs, motivations and value. The review section is followed by the methodology section and a discussion of the findings and conclusions, in which the limitations of the findings are highlighted and future research options are suggested.

\section{Theoretical framework}

\section{Luxury brands and the consumer}

Luxury brands have evolved from being reserved to upper social classes to being accessible for everyone, regardless of class and status, as long as the consumer can afford them. A luxury brand is commonly defined from a producer perspective, as a global brand that concentrates on producing and merchandising exclusive fashion and luxury goods, such as Chanel, Louis Vuitton, and Prada. These brands are associated with exclusivity, one of luxury brands' main characters. Other core characteristics are differentiation, premium pricing, high quality and craftsmanship. (Jackson and Shaw, 2009; Okonkwo, 2007; 2009). Luxury brands often include designer brands like Armani and Calvin Klein that have a main designer whose own design style sets the direction of the brand (Jackson and Shaw, 2009). Due to the two terms' close relation, this study refers to both terms as luxury brands.

From a consumer perspective, luxury products are traditionally defined as goods that may convey prestige to the owner (Grossman and Shapiro, 1988). Uggla and Lashgari (2012) stress that luxury brands extend far beyond their use-value to sign-value due to this feature. One aspects of this is that prestige refers to conspicuous value, which is closely related to the consumer's effort to attain and maintain the social status, which may have been created due to luxury consumption (Vigneron and Johnson, 2004). Another aspect related to this consumption is that luxury products are perceived to attain social meanings like desires to be distinguished from the masses and identified with a group, such as a desired social group (Cova, 1997). Related to the previous aspects; the visibility of these brands brings not only prestige, but also effect on the owner's identity and self-image (Husic and Cicic, 2009). In addition to external and internal benefits, the importance of these brands' premium quality has been proven also for the consumers' (Hung et al., 2011). Based on the previous benefits Berthon et al. (2009) has suggested that the value of luxury brands relates to their functional, 
experiential and symbolic dimensions. Functionality refers to cognitive evaluation such as the perceived quality, experiential value relates to hedonistic benefits like the subjective perceptions of beauty, while the symbolic dimension holds perceived social benefits like prestige while owing the luxury brand.

Hence, consumers are found to use luxury brands to express their own identity, yet luxury brands are seen in particular to contain positive social meanings (Phau and Leng, 2008; Phau and Cheong, 2009). In short, the value lies in extending one's self and conspicuousness (Berthon et al., 2009). Both brand love (Batra et al., 2012) and avoidance (Lee et al., 2009) studies show that the consumer's view of the self has influenced how he or she views brands. In essence, luxury fashion brands may convey individual style yet being a social statement (Amatulli and Guido, 2011). Although luxury brands have attracted a considerable amount of research, little is known about luxury brands as a way for gifting oneself.

\section{Gifting and self-gifting behaviour}

Gifting behaviour can be conceptualised in two ways (Davies et al., 2010): transactional gifting, which is better known in research and refers to consumer-to-consumer gifting and business gifting, and relational gifting, which 'has yet to be fully exploited by researchers' (Davies et al., 2010, p. 414). This latter, little-researched area of relational gifting includes self-gifting as well as tipping, charitable gifting, and file and knowledge sharing among students and academics.

Self-gifting is part of self-directed consumer behaviour (Mick and DeMoss 1990a,1990b). It has been defined as 'personally symbolic self-communication through special indulgences that tend to be premeditated and highly context bound' (Mick and DeMoss, 1990a, 1990b), can include various products (Mick and DeMoss, 1990a, 1900b), and are often provoked by life transitions, relationship disruptions, or changes in work (Mick et al., 1992). Typically, people engage in self-gifting either as rewards for accomplishments or as consolation for disappointments (Mick and DeMoss, 1990a, 1990b). Mick and DeMoss (1990a) identified three dimensions of self-gifting: communication, exchange, and specialness. Communication entails that people communicate with themselves by self-gifting, expressing self-regard, selfesteem, and identity. Exchange refers to consumers' self-gifting after efforts or performances, explaining that they deserve a self-gift (Mick and DeMoss, 1990a). The exchange dimension may act as a self-regulatory incentive in order to achieve a specific type of behaviour, such as 
efficacy, discipline, or self-satisfaction (Bandura \& Schunk, 1981). Specialness refers to particularity, meaning that it is beyond the common sphere of life (Mick and DeMoss, 1990a).

According to Mick et al. (1992) self-gifts are highly context-bound. Mick and DeMoss (1990a, 1990b) describe three different contexts where consumers engage in self-gifting. The first is linked to circumstances in a consumer's life, such as personal accomplishments, disappointments or depression, and holidays. Second, self-gifting occurs as a form of stress relief after an enduring or unpleasant event. Third, self-gifting may be initiated from having extra money for indulging. None of these circumstances are part of normal daily routines, as self-gifting is often linked to something extraordinary that takes place. Mick and DeMoss (1990a) conclude that self-gifting may be a widespread consumption motive even if it has gained limited attention in research (e.g. Davies et al. 2010; Ward and Tran, 2007).

\section{Self-gifting motivations}

Consumer self-gifting motivation has been studied from a first-person perspective and is focused on oneself (Sherry, 1983). Self-gifting exemplifies how consumers self-motivate their own acquisitions and consumption behaviour. Self-gifting has also been seen as the investment of psychic energy to create meaningfulness in acquisitions, which is justified with an implicit or explicit self-contract in order to approve indulgence (Csikszentmihalyi and Rochberg-Halton, 1981).

Investigating consumer motivation is important, because motivation studies provide the basis for understanding consumer behaviour. Ryan and Deci (2000) differentiate between two types of general motivations: intrinsic and extrinsic. Intrinsic motivation refers to doing things because of their inherent pleasure, whereas extrinsic motivation refers to actions spurred by distinct outcomes. While motivations determine the active response, they are guided by needs (Mahatoo, 1989). According to Solomon and Rabolt (2009), 'Consumers select, purchase, use and dispose of products to satisfy needs'. If needs are fulfilled, consumers perceive value, which has been defined as a ratio of benefits and sacrifices (Zeithaml, 1988), and different types of value have been recognized that can obtain positive or negative valence (Sheth et al., 1991). In addition to the functional, experiential and symbolic beneficial dimensions pointed out by Berthon et al. (2009) for luxury brands, Sheth et al., (1991) highlights the emotional benefits that refers to positive emotional responses (Sheth et al., 1991). Notable is that this research stream distinguishes between social benefits, which refer to using visible goods like 
luxury fashion brands, and symbolic benefits, which refer to the fulfilment of internallygenerated needs associated with self-image or role are likely to be important (Park et al., 1986).

According to Holbrook (1994), value has three dimensions: a) extrinsic versus intrinsic, b) self-orientated versus other-orientated, and c) active versus reactive. The first dimension refers to the distinction between an object being a means to achieving some other objects (extrinsic value), or whether it is of value for its own sake (intrinsic value). The second dimension refers to the motivational locus of value. Self-orientated value is driven by selfinterest, whereas other-orientated value refers to value sought for 'the other', whether based on the reactions of others, the effect on others, or 'other' beyond mere self-interest (e.g., the universe, one's subconscious). The third dimension refers to a distinction between active and reactive value. 'Active' means that the subject is acting upon an object or experience, and that activity results in value. 'Reactive' refers to an individual being more passive in the sense that he or she does not engage in manipulative actions, but rather lets the object or experience have its effect (Holbrook, 1994).

A comparison of self-gifting to Holbrook's value dimensions reveals the variety of beneficial dimensions involved with self-gifting. Self-gifting is linked to extrinsic and intrinsic value. Extrinsic value refers to the gift being a means to achieving something else, such as increased feelings of self-worth; intrinsic value refers to the person valuing the gift itself. Second, the motivational locus of value within self-gifting may be driven by self-interest or others' reactions. One may acquire a branded piece of luxury clothing as a self-gift and expect others to show admiration, for example.

Davies et al. (2010) argue that self-gifting is orientated to oneself in nature and thus cannot involve reciprocity. Based on the previous discussion, we do not relate reciprocity only to receiving a gift directly from another person; we rather understand self-gifting as a form of self-communication or self-motivation, where reflections from others are part of the phenomenon. Thus, self-gifting is most likely both internally- and socially-orientated. Notably, the outcome of self-gifting may include positive and negative outcomes, such as satisfaction or guilt, based on sense-making of personal autonomy, self-appraisal, and selfconfirmation (Sherry et al., 1995).

Consumer self-gifting with luxury fashion has attracted limited attention, although it has been shown that self-gifting, together with self-directed pleasure and self-identity are related to the intention to purchase luxury fashion brands (Kim et al., 2011). Amatulli and Guido (2011) 
differentiate between luxury as a social statement, involving aspects like materialism, and luxury as individual style, entailing emotional and hedonistic aspects, culture, and individual lifestyle; therefore, gifting oneself with luxury could follow the same materialismindividualism dimensions. In general, gifting oneself with luxury brands seems to be a rather controversial topic. On one hand, people do seem to engage in self-gifting, but on the other hand, in relation to luxury brands, Roper et al. (2011) point out: 'Yet, to overtly celebrate the luxury brand (at least as a reason for purchase) would be tantamount to joining the 'brand dupes', against which participants' own assertive positions within luxury discourse are founded.' Self-gifting with luxury brands may be perceived as controversial, and thus deviate from mundane self-gifting behaviours.

\section{Methodology}

To explore consumers' perceptions of luxury fashion brands and self-gifting motives a mixedqualitative methods approach was employed; individual, small group and focus group interviews were performed in addition to self-reporting introspection. The employment of multiple data-gathering methods and the use of multiple sources, i.e. triangulation, is a widely used tactic to enhance the quality of the data and the trustworthiness of the findings (Miles and Huberman, 1994; Denzin and Lincoln, 1994). The used data collection methods are deemed suitable for exploring phenomena in-depth (Hine, 2000). The one-to-one interview method is used to gain detailed in-depth beliefs and feelings (Rowley, 2012), and "to glimpse the logic by which the respondent sees the world" (McCracken, 1998, p.9); one of the major benefits being that one-to-one interviews provide circumstances to discuss sensitive and rather personal issues, and the opportunity for probing. Indeed, gifting oneself with luxury fashion brands was perceived as a rather sensitive topic by some of the participants, which was not readily shared in groups. Small group and focus group study energises the participants, and the benefit here is that the methods generate data that is based on the synergy of group interaction (Morgan and Krueger, 1993; Wilkinson, 2004). A focus group interview is unique in that it encourages the participants to interact and respond spontaneously, which may provide more in-depth insights (Krueger and Casey, 2000). Introspection involves selfreporting, i.e. writing about one's own conscious thinking. This type of subjective personal interrogation entails self-reflection of the topic at hand (Patton, 2002) and is a form of 
"participant observation of the researcher's own consumption experiences and the relevant meanings that these evoke" (Holbrook, 2006, p. 716).

\section{Data collection and sample}

This study involved multi-researcher collaboration, meaning that each author collected data. The applied approach is unique, as interpretive consumer research typically involves at most three researchers (The Voice Group, 2008). The ultimate aim for this research design decision was to reduce researcher biases. We used purposeful sampling, which means that we selected respondents that would provide rich information about the topic (Patton, 2002) and would be comfortable talking about the topic with the researcher and with each other in small or focused groups. When it comes to small and focused groups, in order to generate rich data, the participants should be as homogenous as possible, but different enough to facilitate varying perspectives on the investigated topic (Krueger and Casey, 2000). To find respondents providing relevant and rich information, convenience sampling was initially employed, meaning that some participants that the researchers knew were interested in luxury fashion and luxury brands were contacted and interviewed. After the initial convenience sampling, the snowball technique was used to find additional participants. Each participant was asked, if possible, to introduce new potential participants that purchased luxury fashion brands (Creswell, 1998). As the intent was to ensure multiplicity of possible alternative perspectives on the studied phenomenon, variety of age and gender, were used as additional criteria in participant selection (Belk et al., 2013).

To collect data a thematic guide was designed to aid the moderator in directing the discussions in one-to-one and group interviews (Krueger and Casey, 2000). The guide identified main themes in a consistent and systematic manner interposed with probes to elicit more elaborate responses when needed. The guide was also used to make sure that the same themes were reflected upon in self-reported introspection. The first theme functioned as an introduction to the topic, while the two following themes aimed at gaining insights to the studied phenomenon. The themes included were:

- Perceptions and experiences of self-gifting and luxury fashion brands;

- Perceptions and experiences of gifting oneself with luxury and luxury fashion brands; and 
- Motivations therein

The discussions in the small and focused groups were moderated by one or two researchers. At the beginning of the sessions, brief introductions were made by the participants and moderators, and participants were assured of anonymity and confidentiality. One moderator initiated the interviews by asking participants to share their perceptions, experiences, and motivations in purchasing luxury fashion brands. The moderator employed a guided development approach, wherein topics were raised by the moderator and guided the discussion in view of the guide. This approach was necessary to stay within the allocated time, approximately 60 minutes, finishing only when the moderator felt the topic was covered and the participants clearly expressed they had no additional perceptions or experiences to share. The moderator had the freedom to explore topics as they were raised. One-to-one interviews were shorter, lasting about 30 minutes. The discussions were audio-taped and transcribed verbatim. The introspections resulted in written reports that were analysed accordingly.

Six one-to-one interviews, two small group, and two focused group interviews were conducted over a three months period. The introspection and self-report were written during the same time frame. Data collection continued until data saturation and thematic exhaustion was reached, that is, when no new themes emerged and when no new data associated with the existing themes were generated (Morse, 1995). Table 1 lists the number of respondents related to the used data collection method. Altogether, 19 respondents, consisting of men (7) and women (12), were involved in the study, ranging from 18 to 66 years (average 40). Table 2 lists key demographic characteristics.

Insert Table 1 about here

Insert Table 2 about here

\section{Data analysis}

The quality of analysis was ensured by researcher triangulation (Denzin, 1978) meaning that more than one investigator was involved in the process, in this case three of the authors analysed the collected data individually. The initial data analysis was aimed at framing 
concepts and categories, and was performed in two phases. First, the data was coded with descriptive codes that functioned as summarising labels, with little interpretive efforts. To gain an understanding of consumer perceptions of luxury and luxury brands and theory motivations for self-gifting of luxury fashion brands, data analysis aimed at detecting reoccurring explanations. During data analysis, primary themes emerged. In the second phase, data analysis continued in order to detect patterns that would give further insight. Gradually, conceptual patterns appeared to characterise the perceptions of luxury and luxury fashion brands and self-gifting motivators. At the end the three authors met and compared their interpretations to arrive at a common understanding based on individual primary themes, facets, and features. At this phase the themes and facets found were compared to prior research. By having this approach, new insights were highlighted. The study has a consumer research perspective, and the analysis was done with those premises in mind.

\section{Findings}

The data revealed numerous aspects regarding gifting one-self with luxury fashion brands. Related to the focus of the study, the findings highlight participants' perceptions of the selfgifting themselves with luxury fashion brands, their perceptions of luxury fashion brands, and their motivations to gift themselves with the above. Moreover, a number of additional constructs appeared which bring valuable insight to understanding self-gifting behaviour of luxury brands. These are highlighted in the final discussion and suggested as avenues for future research.

\section{The experiential act of self-gifting}

One of the emergent themes was how the participants perceived the act of self-gifting while purchasing luxury fashion brands for themselves. The most essential finding was that selfgifting holds experiential aspects. This is due to the fact that it is a process and involves emotions that contribute to the experiential act. Further, the data revealed that self-gifting is mostly predetermined, yet it may also be impulsive.

To begin with, one of the core findings was that the act of self-gifting is an experience. Past research stresses that shopping has utilitarian means (Milan and Howard, 2007), while it also 
serves hedonistic means as it can be a source of relaxation (Dholaki, 1999) and pleasure (Clarke and Belk, 1979). In the current self-gifting context the hedonistic means were more apparent than the utilitarian ones. In some cases the core act of self-gift shopping was perceived as such a positive experience - a luxurious one - that it overrode the brand importance:

And then of course there are these boutiques, and Lingon \& Blåbär (a Swedish middle-price home-party brand) - it is the people [who attend the party], and the spirit... and [the products] are pretty, not everybody who comes around has them... and there is always some small design thing - and in the boutiques, there are really good personnel who can give advice, that is luxury too.

In the previous example the brand may not be defined as luxury fashion brand due to its premium price or craftsmanship (e.g. Jackson and Shaw, 2009; Okonkwo, 2007). Yet, the respondent defined the brand as luxurious due to the perceived high quality, aesthetics and exclusivity. This may be due to the fact that as the respondent pointed out, few in her reference group (retired women) wear Lingon \& Blåbär, which is typically bought by mothers with young children.

However, the importance of the experiential act of gift shopping was also detected while shopping luxury fashion brands that met the traditional product definitions:

We have this kind of little ritual, we go as a group of friends to Bicester (a retail outlet park) to have a shopping day, and then we go from one shop to another, and we spend at least 45 minutes at this one shop, and then each one of us buys something, that there is this kind of, not peer pressure but there is this kind of dance of its own. But it is fine if you've budgeted for it in advance...

This example shows that despite a self-orientated act, self-gifting can hold social-orientated aspects like shared experiences and rituals. Whereas previous research (Luomala and Laaksonen, 1999) has suggested that this type of active and social self-gifting behaviour is mood-maintaining, it is here interpreted as mood-creating, since the respondent had planned the trip in beforehand. Thus, the act of shopping for luxury fashion brands was not a reaction to a mood state, but rather was undertaken to create meaningful experiences that in turn influenced the respondent's mood.

Second, the findings reveal that self-gifting is a process suggesting that the act of such gifting is not limited to the core purchasing situation. Research within consumer experiences implies 
that experiences occur during various phases of a consumption situation, either before, during, or after the purchase (Arnould et al., 2002; Holbrook and Hirschman, 1982). Similar findings were detected here while studying self-gifting. For example, the potential act of saving money and the rituality reveal that the self-gifting experience may well start before the core act of shopping. Moreover, the gifting experience does not stop with the purchase, but continues while owning the luxury fashion brand. It appeared that the gifting experience of the luxury fashion brand gained importance after purchase in some cases: 'I wanted to buy something new [luxurious] that I can remember of my farewell [for retirement]'.

Third, the self-gifting shopping experience holds intense emotions. Research within consumer experiences stresses that the intensity of experiences differs, varying from being perceived as extraordinary, involving perceptions of newness (Arnould and Price, 1993) or uniqueness (Wooliscroft and Ganglmair-Wooliscroft, 2009) to being mundane (Carú and Cova, 2003). Our data reveals that consumers relate intense emotions to luxury. These were related to the shopping experience, while purchasing oneself a gift perceived as a luxury fashion brand. In fact, even a self-gifting act of shopping may be perceived as a luxurious experience as it is perceived as extraordinary and unusual, and not mundane at all. Then again intense emotions were related to the brand itself that was perceived as luxury fashion; 'It feels like an ... emotional kick ... It feels real cool...'.

Fourth, past research stresses that self-gifting is both predetermined and impulsive (e.g. Atalay and Meloy, 2006). In the current self-gifting context with luxury fashion brands the act of self-gifting appeared to be more commonly predetermined; "they are things that I usually think about in advance ... they are not unconsidered'. Hence these purchases involved the predetermined initiative - the act of self-gifting - and the monetary sacrifice. As one respondent said: 'But yes, I could have bought an H\&M jacket...' and 'sometimes one asks was it [the fashion luxury brand] necessary - ... usually it was [not an utilitarian necessity, but a hedonistic one]...'. What also appeared was that although the act of self-gifting was predetermined, the specific purchase could be impulsive. The following citation shows how a wider shopping experience may initiate the specific self-gifting act: 'I bought a suit (from Ted Baker)... It was an impulse, I wasn't looking for anything in particular [referring to the selfgift] but then I just found it and the service was so good that I ended up buying it for me'.

\section{Nature of luxury fashion brands}


Further analysis of the participants' perceptions of luxury fashion brands resulted in six specific features defining luxury fashion brands. These are listed in Table 3. Upon completion of the analysis, it was apparent that all participants reported these features which repeatedly appeared during the interviews. Luxury fashion brands are by nature multifaceted. To begin with they relate to intrinsic and extrinsic product characteristics. Accordingly, these brands were perceived as being of higher quality '... the value of quality and the [luxury fashion] brand' and premium-priced '[brand name] can be extremely priced ... but at the same time fairly priced' in accordance with the traditional definitions of luxury fashion brands (Jackson and Shaw, 2009; Okonkwo, 2007; 2009; Husic and Cicic, 2009).

Insert Table 3 about here

The findings also revealed that luxury fashion brands are perceived as something exclusive and unique - unreachable for most consumers in accordance with the definition of luxury fashion brand (e.g. Jackson and Shaw, 2009). As one respondent pointed out when he thought about luxury fashion: '[They are] the kind of products that are not all over the place, like generally, they are more like unique products'. One respondent pointed out that: 'I think someone who is able to afford brand-named luxurious fashion every day of the week, for example Dolce \& Gabbana, I don't think that they think that it is luxurious because it is more expensive. I think they feel like it is luxurious because not everyone can have it and wear it as often as they can.' Related to exclusivity, the participants pointed out that something becomes luxury when it is reachable, but not on an everyday basis and not for everyone: 'something that you can't afford all the time' and 'most people don't have it'.

Some of the participants noted the difference between luxury fashion and luxurious fashion:

'Fashion for me is the clothing and shoes and bags and such that are shown on the runway, where all the designers come with their new collections and such... which are often quite peculiar and extreme and nothing that would attract me as such—when I'm thinking about luxury fashion so perhaps it is these very unique, expensive pieces perhaps I have bought [luxurious fashion], perhaps when Karl Lagerfeldt worked together with H\&M I have bought a piece of clothing there'. 
Here, luxury is linked to the designer, known for his own style (Jackson \& Shaw, 2009). Past research defines that designer brands are by definition exclusive (Jackson and Shaw, 2009; Okonkwo, 2007) and unreachable for most consumers. They may be accessible, but in practice are indeed unreachable as they are unaffordable. Yet, various marketing activities can make the unreachable reachable, conveying uniqueness instead as the citation above attempts to illustrate. Hence, by the traditional luxury definition H\&M is not a luxury fashion brand, yet the perception of luxury is conveyed by the particular designer collection.

Basically luxury fashion brands were perceived as something not mundane; they deviate from brands and products purchased normally: 'If you have something every day then that wouldn't be considered luxurious any more'. These findings are in line with those of Vigneron and Johnson (1999) regarding prestige: it only exists if not everybody has it. Another participant pointed out that in order to be luxury, it has to be sufficiently deviant from the everyday: 'I feel that it is something beyond the normal, sufficiently deviating from the normal, the limit goes somewhere, I suppose'. Luxury holds a dimension of being something additional to the mundane: 'Luxury is that something extra... better than weekday'. This suggests that luxury brands hold intangible benefits (Uggla and Lashgari, 2012), being extraordinary in comparison to the mundane..

The findings support that luxury fashion brands are related to higher levels of quality and price, exclusivity and uniqueness as pointed out by past research (Jackson and Shaw, 2009; Okonkwo, 2007; Husic and Cicic, 2009). The data revealed that such brands also relate to deviation from the mundane and to being extraordinary. In essence, the findings imply that the perception of luxury fashion brand is subjective and relative. This means that what is perceived as expensive by one consumer may not be that for someone else. This concerns all the other features as well.

\section{Motives for self-gifting with luxury brands}

Our findings reveal a large number of motives for gifting oneself with luxury fashion brands, which where categorised into two themes; self-gifting as a means of self-communication and social communication. We use the concept of communication here as luxury fashion brands appeared as a means of communication; either for oneself or in a social context (e.g. Mick and DeMoss, 1990). 


\section{Self-gifting as self-communication}

One essential reason for gifting oneself with luxury was evidently self-communication, which supports past findings detected with mundane products (Mick and DeMoss, 1990). This type of self-gifting is self-orientated (Holbrook 1994), since it is evoked within the person $\mathrm{him} /$ herself and is explained by personally-orientated motives (Tsai, 2005; Wiedmann et al., 2007). As one respondent reflected: "I get this urge every two-three months or so that I have to buy something for me, and then I purchase immediately online brands such as Paul Smith, Storm or Ted Baker'. This means that the consumers gift themselves with luxury fashion brands, where the gift carries mainly intangible, but also some tangible benefits for the consumer. From the analysis the following motivations emerged explaining participants' internal motivations: utility and such experiential benefits as remuneration (incl. incentive), consolation, allowance, self-regard, indulgence, nostalgia, and celebration (see Table 4).

Insert Table 4 about here

One motive that appeared for gifting oneself with fashion luxury brands was the perceived utility value - functional benefit - of these products, a kind money saving act: " Better to buy something expensive; it lasts'. Another respondent, who despised luxury fashion brands and associated luxury with paying for the brand name, pointed out that a luxury fashion brand [that he felt had a negative connotation] could in time become a functional product - having tangible benefits, and thus explained the purchase: 'I bought these running shoes, ... sickly expensive. But good ...they are high tech, perhaps, in a way that it can be that they work, if you think about it they are really useful. And they have shown to be extraordinary".

Past research stresses that people engage in self-gifting as rewards for accomplishments, stress-relief after accomplishments, and as consolation for disappointments (Mick and DeMoss 1990). One essential reason for self-gifting was remuneration: 'Luxury fashion...you are able to afford it once in a while to reward yourself.' Not only rewarding, but also selfgifting as an incentive were often linked to an achievement of something ' ... as a carrot [cultural expression] for getting something done and to survive [before the set goal is achieved]'. The remuneration can be for something forthcoming, yet it could also be a reward decided upon after the achievement: '..I had invested so much, so I rewarded myself ...'. 
Our findings with luxury brands support also the means of consolation, but not as a means of relieving oneself due to stress. Hence, another essential reason for purchasing luxury brands for oneself related to an effort or performance was a sort of consolation after an unpleasant experience 'it didn't go so well .....and in order to console myself ... '. Consolation did not have to be related to disappointment only and need not even be triggered by a specific effort or performance. Hence, self-gifting as means of consolation appeared also due to respondents' current emotional state, yet not due to depression as suggested by Mick and DeMoss (1990). Instead, it appeared as a mood stabiliser, 'if it feels grey and gloomy'.

Participants motivated their luxury self-gifting by saying they seldom have time to be by themselves or to think of themselves, which means that they occasionally allowed themselves to purchase something extraordinary. Allowance was also expressed as in 'I allowed myself an expensive bag'. In these cases the luxury fashion brand communicated an effort allowed to oneself: 'now I will buy you - little missus - this small thing, so please be quiet for a half month again". Allowance was not related to any particular need-state, yet it was closely related to self-regard. Yet self-regard is more related to a state, where something is missing and must be done. This was expressed 'I need to take care of myself' - a notion supported by past research (Mick and DeMoss, 1990a).

Self-gifting with luxury fashion brands was also motivated by indulgence or pampering. This was not linked to a specific effort or performance, nor to any emotional state of mind, which could indicate consolation. Only one participant mentioned the hindering monetary aspect related to self-gifting with luxury, which was related to a concern about affording pampering (Mick and DeMoss, 1990a). Indulgence was expressed by 'more expensive accessories and such things, which make you feel better,' and 'I have needed it [luxury fashion brand] to feel better'. The indulgence appeared as a means to ensure a state of mind and to strengthen the current one: 'luxurious fashion ... can be something that makes you feel good or ... great'. Luxury fashion brands were bought for oneself as means of bliss and contentment (Kim et al., 2011). Hence, this motive was closely related to being nice to one self as detected by Mick and DeMoss (1990a, 1990b; 1992).

Interestingly, nostalgia appeared as a reason for self-gifting with a specific brand that can be perceived as a luxury fashion brand: 'it may be nostalgia or at least with Burberry ... it has the link to England, where my parents have lived and my sisters still live'. Here, the sense of brand nostalgia originates in the respondent's excuse, or rationalisation, for the purchase. The particular self-gifting could also carry intangible benefits, such as prolonging emotionally- 
laden past experiences and memories (Holak and Havlena, 1992) as 'it is more the abstract that is important for me if I buy Burberry'.

Participants also bought gifts for themselves due to celebrations - special events, like birthdays and retirements. This is a reason noted by Mick and DeMoss (1990). Here, the gifting was explained by wishing to have something tangible as a reminder of the event: 'I bought a Burberry shirt when it was my farewell party [for retirement] - I wanted to buy something new that I can remember of my farewell'. Again, the purchases do not seem to have any social means, but are related to the self only: 'Once I bought this watch for myself as a birthday present, I really bought it just for me-It was luxury - It is a Rolex - It is not about showing up for others that is the luxury of it, but to have it.'

As it appears the current study supports the findings of past research that one gifts oneself with luxury fashion brands as means of remuneration (incentive), consolation, self-regard, indulgence and celebration (Mick and DeMoss 1990a, 1990b; 1992, Weisfeld-Spolter and Thakkar, 2012). The fact that the study did not detect motives like to cheer oneself up and as therapy, to relieve stress, because one had extra money to spend, could be related to the monetary value that luxury fashion brands hold. As pointed out earlier these self-gifting purchases were often predetermined, sometimes based on money saving acts. Then again the study found such motives like utility, allowance and nostalgia, which has not been noted by past self-gifting research in the context of luxury fashion brands.

\section{Self-gifting as means of social communication}

Another essential reason for self-gifting with luxury was social communication (Mick and DeMoss, 1990). This type of self-gifting is extrinsic in nature, since it aims at social communication means that consumers buy luxury brands for themselves for sociallyorientated reasons and motives, for a distinct outcome (Ryan and Deci, 2000), or their visibility (Park et al., 1986). All expressions were analysed further in order to develop constructs summarizing the motivations. The emerging constructs are summarised in Table 5 below. Five socially communicative motivations emerged from the data explaining external motivations for gifting with luxury: impression, confidence, credibility, belonging, and approval. Each motive holds symbolic aspects related to social benefits of owing luxury fashion brand. 
Insert Table 5 about here

One reason for gifting oneself with luxury appeared to be explained by a desired impression one wants to give others: 'you really, really need to dress to impress somebody' and 'I would say that brand clothing is not really to impress on others, but, maybe it is part of it'. This motive may be perceived as a self-centred motivation for self-gifting, yet is a motive for giftgiving as well (Valentin and Allred, 2012).

Secondly, related gifting one-self with luxury fashion brands was explained by the internal feeling of confidence that these brands may provide: 'it makes you feel better ... more confident'. The importance of self-confidence is supported by Amatulli and Guido (2011). An interesting, new aspect came up when one respondent referred to the purchase of a luxury fashion garment bringing forth a promise of an aspired self: 'Nevertheless, those clothes (Boss) are so attractive, they convey the promise of a more efficient, to the point, more sensible me. And I mean the 'working me', I have no aspiration to be like that at home'. For this respondent, the purchase of the luxury fashion garment offered a new way of seeing oneself. Notable is that confidence was not related to oneself as a means of indulgence, but more about how the luxury brand makes one feel in a social context.

A third reason explaining other-orientated self-gifting was the sense of credibility luxury fashion brands gives oneself in a social context: "I think just by dressing nicely and dressing in fashion, dressing in style, ... people are more likely to take you seriously and treat you better.' Then again: 'Appearance is very important to be in favour of other people”. Similarly, one respondent reflected upon the relation of the perceptions of self and those held by others: 'If I am a person who goes around with clothing that was stylish for five years ago and that is decayed here and there -why would anybody else appreciate me if even I do not appreciate myself?'

One essential reason for self-gifting with luxury was the sense of belonging. The contexts of school, where one works, lives, and intends to travel to were repeatedly mentioned: 'Otherwise you would consider it as weird or something like that, not to be associated with everybody else'. An interesting aspect was that the respondents acknowledged that the social context varied: 'For me it was luxury when I bought a Tommy Hilfiger coat... but there is a difference (in whether I will feel better or not) depending on if I'm with these half-friends at 
[...] school or with acquaintances or other friends, with them it does not matter what I wear, but with these school mates... you just don't want to say that you went to H\&M. So sometimes it [the brand] matters, it has a bigger importance if others care and comment and such'.

Approval of the purchased item was perceived as essential. The social influence on selfgifting behaviour may relate to the first purchase: 'It [positive feedback] probably influences the next purchase decision, for example when I for the first time bought an Anya Hindmarch bag, I got an enormous amount of positive feedback, and .. I'm terribly prone to please others.'

To conclude, the data revealed that although self-gifting is self-orientated, the social orientated motives were often used to justify the self-gifting act. Hence, a luxury fashion brand could have been bought for a reason like a self-reward. While it was not perceived as a sufficient motive, additional motives were needed, such as a desire for belonging or a justification made after the act of self-gifting like approval.

\section{Discussion and future research avenues}

The study has focused on self-gifting with luxury fashion brands, exploring the topic with a multi-qualitative approach to contribute insights to consumers' motivations to gift one-self explicitly with luxury brands. There is an inherent contradiction in the self-gifting with luxury fashion brands in that self-gifting is orientated to one-self in its nature (Davies et al. (2010), whereas luxury purchases are seen as social statements (Amatulli and Guido (2011). Our findings reveal that reflections from others are part of the self-gifting phenomenon. It appeared that although self-orientated values and personally-orientated motives trigger the self-gifting act, the act of actually purchasing explicitly luxury brands for oneself as a gift may be triggered by other-orientated values and socially-orientated motives (Holbrook, 1990). Our findings also imply that luxury fashion brands hold a self-orientated aspect; luxury brands are not only purchased for socially-orientated reasons but also for reasons related to oneself.

The study also revealed a set of personally-orientated motives that contribute to understanding why consumers purchase luxury fashion brands for one-self. By detecting these motives the study responds to the requests by Kim et al. (2011), who stress that those motives have been overlooked. The study found that some of these personally-orientated motives where related 
to an event or performance (remuneration, consolidation, allowance, self-regard, nostalgia, celebration), whereas others were not linked to any specific effort (consolidation, utility, indulgence). The study also found that the motivation of consolation was occasionally related to a specific event or performance, and also occurred without any link to an event due to a sort of lightweight reasoning, such as mood.

In addition to being able to relate some of the dimensions as personally orientated and others as socially-orientated motives, the study detected underlying triggers serving both means. For example, consumers' desire to pamper oneself or impress others can be triggered by underlying aesthetic motives. Another interesting aspect underlying motives for self-gifting was consumers' need to rationalise and justify extraordinary self-gifting purchases. Purchase of luxury brands may be perceived as problematic as it is against ones' values. In these cases rationalisation did not trigger the motive, such as to pamper oneself or impress others, but was used as an excuse for the purchase. This conclusion is related to the fact that the data revealed a sense of guilt apparent both before the core self-gifting act, during purchasing, and after the act of gifting oneself. This appeared as a sort of soul-searching, which indeed future research could explore further. It appeared that this reflection was linked to self-guilt but also to a form of "other-guilt".

In addition to the motives for gifting oneself, the study contributes to understanding consumers' perceptions of luxury brands. Past research has tested a number of dimensions (hedonic, uniqueness, quality, extended self, conspicuousness) among various segments of consumers (Christodoulides et al., 2009; Vigneron and Johnson, 1999; 2004) and various dimensions have been confirmed. Our open-ended approach revealed that luxury brands are subjectively determined by individuals. For example, we found that in line with previous research, luxury fashion brands are perceived as something exclusive, but that "exclusivity" is a relative concept, meaning that what someone experiences as exclusive is not necessarily experienced as exclusive by someone else. Similar findings have been reported in other marketing contexts, such as for example, service quality (e.g. Grönroos, 1992). Thus, luxury fashion brands were perceived as being something deviant, holding extraordinary benefits (hedonic), being unique and exclusive, and holding intrinsic and extrinsic product characteristics. The fact that our study did not reveal aspects of extended self and conspicuousness may suggest that they are a cultural issue. The study was done in a Nordic context, where people's appearance and self-being is modest. Our study emphasises the perceptions of deviation, exclusivity, and the monetary value linked to luxury brands. In 
essence, luxury was contrasted with mundane, and the benefits of gifting oneself with luxury in contrast to something mundane were that luxury in itself was perceived as extraordinary. These findings provide valuable knowledge for practitioners such as fashion brand managers, as they plan for services and offerings that allure consumers who self-gift. These self-gifting motives could be employed as the basis for marketing activities. For example, marketers could capture the essence of "remuneration" or "celebration" in their marketing activities like in store displays as a means to connect with consumers who want to reward themselves after working hard to achieve a goal or consumers who want to celebrate an occasion.

The study holds limitations, which provide several avenues for future research. To begin with, the current exploratory qualitative research design could be developed further to incorporate a bigger sample. Related to the characteristics of the sample, some of the dimensions appear to be culturally-bounded, which suggests that a cross-cultural study would bring valuable insights to understanding the cultural issue of luxury perception, luxury fashion brands, and motives to gift oneself with luxury fashion. In addition, the findings deserve validation by using other research methods. The findings of the study suggest that self-gifting is a process, where motives may change throughout. It is possible that consumers move from sociallyorientated motives to personally-orientated reasons, and the motives of rationalisation may have various effects. Hence, the link between rationalisation and personally- and sociallyorientated motives deserves scholarly attention. The finding that luxury was also related to the shopping experiences of luxury brands could be studied further. Our study detected that luxury experiential perception did not stop with the purchase, but the experience continues while owning the purchase. Also, it appeared that the luxury brand gains importance after the purchase in this context.

\section{References}

Amatulli, C. and Guido, G. (2011), "Determinants of purchasing intention for fashion luxury goods in the Italian market: A laddering approach", Journal of Fashion Marketing and Management, Vol. 15 No. 1 pp. 123-136

Atwal, G. and Williams, A. (2009), "Luxury brand marketing - The experience is everything!”. Brand Management, Vol. 16 No. 5/6, pp. 338-346.

Bandura, A. and Schunk, D. (1981), "Cultivating Competence, Self-Efficacy, and Intrinsic Interest through Proximal Self-Motivation", Journal of Personality and Social Psychology. Vol. 41 No. 3, pp. 586-598. 
Belk, R., Fischer, E. and Kozinet, R.V. (2013), Qualitative consumer and marketing research, Sage Publications, Thousand Oaks, CA

Belk, R.W. (1979), “Gift-giving behavior”, Research in Marketing, Vol. 2, pp. 95-126.

Berthon, P.R., Pitt, L., Parent, M. and Berthon, J.P. (2009), “Aesthetics and ephemerality: observing and preserving the luxury brand", California Management Review, Vol. 52 No. 1, pp. 45-66.

Caru, A., and Cova, B. (2003), "Revisiting consumption experience", Marketing Theory, Vol. 3 No. 2, pp. 267-286.

Choo, H.K., Moon, H., Kim, H, and Yoon, N. (2012), "Luxury customer value”, Journal of Fashion Marketing and Management, Vol. 16 No. 1 pp. 81-101.

Clarke, J. (2008), "Experiences as gifts: from process to model”, European Journal of Marketing, Vol. 42, No. 3/4, pp. 365-389.

Clarke, K. and Belk, R. W. (1979), "The Effects of product involvement sad task definition on anticipated consumer effort", Advances in Consumer Research, Vol. 6 (ed.) William L. W. , Ann Arbor: Association for Consumer Research, pp. 313-318.

Cova, B. (1997), "Community and consumption: towards a definition of the 'linking value' of products or services”, European Journal of Marketing, Vol. 31 No. 3/4, pp. 297-316.

Csikszentmihaiyi, M. and Rochberg-Haiton, E. (1981), The Meaning of Things: Domestic Symbols and the Self, Cambridge University Press, Cambridge.

Davies, G., Whelan, S., Foley, A. and Walsh, M. (2010), “Gifts and Gifting”, International Journal of Management Reviews Vol. 12 No. 4, pp. 413-434.

Denzin, N.K. (1978), The research act: A theoretical introduction to sociological methods, McGraw-Hill, New York.

Denzin, N.K. and Lincoln, Y.S. (1994), Handbook of qualitative research, Sage Publications, Thousand Oaks, CA.

Grossman, G. and Shapiro, C. (1988), "Foreign counterfeighting and status goods", The Quarterly Journal of Economics, Vol. 103, No. 1, pp. 79-100.

Hine, T. (2000), "An evaluation of two qualitative methods (focus group interviews and cognitive maps) for conducting research into entrepreneurial decision making", Qualitative Market Research: An International Journal, Vol. 3 No.1, pp. 7-16. 
Holak, S. L. and Havlena, W. J. (1992), "Nostalgia: An exploratory study of themes and emotions in the nostalgic experience", Advances in Consumer Research, Vol. 19, pp. 380-387.

Holbrook, M.B. (2006), "Consumption experience, customer value, and subjective personal introspection: An illustrative photographic essay", Journal of Business Research, Vol. 59 , pp. 714-725

Hung, K-P., Chen, A.H., Peng, N., Hackley, C., Tiwsakul, R.A. and Chou, C-L. (2011), "Antecedents of luxury brand purchase intention", Journal of Product \& Brand Management, Vol. 20 No. 6, pp. 457-467.

Husic, M. and Cicic, M. (2009), "Luxury consumption factors", Journal of Fashion Marketing and Management Vol. 13 No. 2, pp. 231-245

Jackson, T. and Shaw, D. (2009), Mastering Fashion Marketing, Palgrave Macmillan, Hampshire.

Kemp, S., Richardson, J. and Burt, C.D.B. (2011), “A goat for Christmas: exploring thirdparty gifts”, Journal of Managerial Psychology, Vol. 26 No. 6, pp. 453-464.

Kim, H-Y, Yoo, J-J, Choi, D., Kim, J. and Johnson, K.K.P. (2011), "Personal luxury values associated with fashion brand consumption: an exploratory analysis of demographic variations in the United States", Journal of Global Fashion Marketing, Vol. 2 No. 3, pp. 130-138.

Krueger, R.A. and Casey, M.A. (2000), Focus Groups: A Practical Guide for Applied Research, 3rd ed., Sage Publications, Thousand Oaks, CA.

Lee, M.S.W., Motion, J, and Conroy, D. (2009), "Anti-consumption and brand avoidance", Journal of Business Research, Vol. 62 No. 2, pp.169-180.

Luomala, H. and Laaksonen, M. (1999), “A qualitative exploration of mood-regulatory selfgift behaviors", Journal of Economic Psychology, Vol. 20 No. 2, pp. 147-182.

McCracken, G. (1988), The long interview, Qualitative research methods series 13, Sage Publications, Newsbury Park, CA

McIntyre, D., Sauter, M. and Stockdale, C. (2011), “Top 10 Things Americans Waste the Most Money On", available at: http://www.topstockanalysts.com/index.php/2011/02/28/top-10-things-americanswaste-the-most-money-on/ (accessed 28 February 2011).

Mick, D.G. and DeMoss, M. (1990a), "To me from me: A descriptive phenomenology of selfgifts", 17, Advances in Consumer Research, in Goldberg, M. E., Gorn, G. and Pollay, R. W. (eds), Pollay, Provo, UT: Association for Consumer Research, pp. 677-682. 
Mick, D.G. and DeMoss, M. (1990b), "Self-gifts: Phenomenological insights from four contexts", Journal of Consumer Research, Vol. 17 No. 3, pp. 322-332.

Mick, D.G., DeMoss, M. and Faber, R.J. (1992), “A Projective Study of motivations and meanings of self-gifts: Implications for Retail Management", Journal of Retailing, Vol. 68 No. 2, pp. 122-144.

Miles, M.B and Huberman, A.M. (1994), Qualitative data analysis, 2nd ed., Sage Publications, London

Morgan, D.L. and Krueger, R.A. (1993), "When to use focus groups and why", in Morgan, D.L. (Ed.), Successful Focus Groups, Sage Publications, London, pp. 3-19.

Morse, J. M. (1995), “The significance of saturation”, Qualitative Health Research, Vol. 5, pp. 147-149.

Okonkwo, U. (2007), Luxury Fashion Branding: Trends, Tactics, Techniques, Palgrave Macmillan, Hampshire.

Okonkwo, U. (2009), "Sustaining the luxury brand on the Internet", Journal of Brand Management, Vol. 16, pp. 302-310.

Park, C.W., Jaworski, B.J. and MacInnis, D.J. (1986), "Strategic Brand Concept-Image Management”, Journal of Marketing, Vol. 50 No. 4, pp. 135-145.

Park, H-J, Rabolt, N-J, Jeon, K. S. (2008) "Purchasing global luxury brands among young Korean consumers", Journal of Fashion Marketing and Management, Vol. 12 No. 2, pp. $244-259$.

Phau, I.Y., and Cheong, E.N. (2009), "How young adult consumers evaluate diffusion brands: effects of brand loyalty and status consumption", Journal of International Consumer Marketing Vol. 21 No. 2, pp. 109-123.

Phau, I. and Leng, Y.S., (2008), “Attitude toward domestic and foreign luxury brand apparel”, Journal of Fashion Marketing and Management, Vol. 12 No. 1, pp. 68-89.

Roper, S., Caruana, R., Medway, D. and Murphy, P. (2013), “Constructing luxury brands: exploring the role of consumer discourse", European Journal of Marketing, Vol. 47 No. 3/4, pp.375-400.

Rowley, J. (2012), "Conducting research interviews", Management Research Review, Vol. 35, No. 3/4, pp. 260-271.

Ryan, R M. and Deci, E L. (2000), "Intrinsic and extrinsic motivations: Classic definitions and new directions", Contemporary Educational Psychology, pp. 54-67 
Schiffman, L.G. and Cohn, D.Y. (2009), "Are they playing by the same rules? A consumer gifting classification of marital dyads", Journal of Business Research, Vol. 62 No. 11, pp. 1054-1062.

Sherry, J.F., McGrath, M.A. and Levy, S.J. (1995), Monadic Giving: Anatomy of Gifts Given to the Self, Sherry, J.F. (ed), Contemporary Marketing and Consumer Behaviour: An Anthropological Sourcebook. Sage, Thousand Oaks, CA, pp. 399-432.

Sheth, J. N., Newman, B. I. and Gross, B. L. (1991). Why we buy what we buy: A theory of consumption values. Journal of Business Research, Vol. 22, pp. 150-170.

Simmel, G. (1957), "Fashion”, American Journal of Sociology, Vol. 62, pp. 541-558. Original work published (1904).

Smith, A. and Sparks, L. (2009), "It's nice to get a wee treat if you've had a bad week: Consumer motivations in retail loyalty scheme points redemption, Journal of Business Research, Vol. 62, pp. 542-547.

Solomon, M.R. and Rabolt, N.J. (2009). Consumer behavior in fashion. 3. ed. Prentice Hall, New Jersey.

The Voice Group (2008), "Reflections on Collaboration in Interpretive Consumer Research", Qualitative Market Research: An International Journal, Vol. 11 No. 2, pp. 147-165.

Tsai, S. (2005), "Impact of personal orientation on luxury-brand purchase value", International Journal of Market Research, Vol. 47 No. 4, pp. 429-454.

Turttle, B. (2012), "Season of giving? Holiday shopping hits new heights of selfishness with 'self-gifting", Time, Oct 19. http://business.time.com/2012/10/19/season-of-givingholiday-shopping-hits-new-heights-of-selfish-with-self-gifting/ (12.6.2013)

Uggla, H. and Lashgari, M. (2012), "Portfolio Strategy for Luxury Partner Brands: Strategic Guidelines", Journal of Brand Management, Vol. IX, No. 2, 18-28

Vigneron, F. and Johnson, L.W. (1999), “A review and a conceptual framework of prestigeseeking consumer behaviour”, Academy of Marketing Science Review, Vol. 99 No. 1, pp. 1-15.

Vigneron, F. and Johnson, L.W. (2004), "Measuring perception of brand luxury", Journal of Brand Management, Vol. 11 No. 6, pp. 484-506.

Ward, C.B, and Tran, T. (2007), "Consumer Gifting Behaviors: One for You, One for Me?", Services Marketing Quarterly, Vol. 29, No. 2, pp. 1-17. 
Weisfeld-Spolter, S., and Thakkar, M. (2012), “A framework for examining the role of culture in individuals' likelihood to engage in self-gift behaviour", Academy of Marketing Studies Journal, Vol. 16 No. 1, pp. 39-52

Wiedmann, K.P., Hennigs, N. and Siebels, A. (2007), "Measuring consumer's luxury value perception: a cross cultural framework", Academy of Marketing Science Review, Vol. 11, No. 7, pp. 1-21.

Wilkinson, S. (2004), "Focus group research", in Silverman, D. (Ed.), Qualitative research: Theory, method and practice, 2nd ed., Sage Publications, Thousand Oaks, CA, pp. 177-199.

Zeithaml, Valarie A. (1988), "Consumer perceptions of price, quality and value: A means-end model and synthesis of evidence", Journal of Marketing, Vol. 52 No. 3, pp. 2-22. 
Table 1: Samples per data collection

\begin{tabular}{llll|l}
\hline & $\begin{array}{l}\text { No. of } \\
\text { participants }\end{array}$ & $\begin{array}{l}\text { Participants/ } \\
\text { group }\end{array}$ & $\begin{array}{l}\text { No. interview } \\
\text { sessions }\end{array}$ & $N$ \\
\cline { 2 - 5 } On-on-one interviews & 6 & 2 & 4 & 6 \\
Small group interviews & & 3 vs. 4 & 2 & 4 \\
Focus group interviews & 2 & 2 & 7 & 2 \\
Introspection & & & 1 & 19 \\
\hline
\end{tabular}


Table 2: Participants' key characteristics

\begin{tabular}{|c|c|c|c|c|c|c|c|}
\hline $\begin{array}{l}\text { Data collection } \\
\text { method }\end{array}$ & Gender & $\begin{array}{l}\text { Marital status/ } \\
\text { number of } \\
\text { children }\end{array}$ & Age & $\begin{array}{l}\text { Data collection } \\
\text { method }\end{array}$ & Gender & $\begin{array}{l}\text { Marital status/ } \\
\text { number of } \\
\text { children }\end{array}$ & Age \\
\hline \multirow[t]{4}{*}{ Focus group 1} & Woman & Single & 24 & $\begin{array}{l}\text { One-on-one } \\
\text { interview }\end{array}$ & Woman & Single & 32 \\
\hline & Woman & Married; 2 & 39 & & Woman & Married; 4 & 63 \\
\hline & Woman & Married; 3 & 53 & & Man & Single & 63 \\
\hline & Woman & Married; 2 & 44 & & Woman & Married; 2 & 33 \\
\hline \multirow[t]{3}{*}{ Focus group 2} & Man & Single & 18 & & Man & Married; 2 & 36 \\
\hline & Man & Single & 21 & & Man & Married; 4 & 63 \\
\hline & Man & Single & 22 & Small group 1 & Woman & Married; 3 & 35 \\
\hline \multirow[t]{3}{*}{ Introspection } & Woman & Married; 2 & 39 & & Woman & Married; 4 & 38 \\
\hline & Woman & Married; 4 & 48 & Small group 2 & Woman & Single & 27 \\
\hline & & & & & Man & Married; 2 & 66 \\
\hline
\end{tabular}


Table 3: Features explaining the nature of luxury brands

\begin{tabular}{ll}
\hline Feature & Participant response \\
\hline $\begin{array}{l}\text { Intrinsic product } \\
\text { characteristics }\end{array}$ & 'Better quality' \\
$\begin{array}{l}\text { Extrinsic product } \\
\text { characteristics }\end{array}$ & $\begin{array}{l}\text { 'It is valued more' } \\
\text { 'It is expensive' } \\
\text { Exclusive }\end{array}$ \\
& $\begin{array}{l}\text { 'Not everyone can have it' } \\
\text { 'Not everybody who comes around has them' } \\
\text { Unique }\end{array}$ \\
'Special in some way' \\
'Somiant & $\begin{array}{l}\text { 'More luxurious than what I normally get' } \\
\text { 'Can't afford everyday' } \\
\end{array}$ \\
Extraordinary & 'Something in addition to the normal' \\
& 'Something extra' \\
\hline
\end{tabular}


Table 4: Motivations explaining self-gifting as means of self-communication

\begin{tabular}{|c|c|}
\hline Motivation & Participant response \\
\hline Utility & $\begin{array}{l}\text { 'It is practical' } \\
\text { 'Better to buy something expensive; it lasts' }\end{array}$ \\
\hline $\begin{array}{l}\text { Remuneration, } \\
\text { incentive }\end{array}$ & $\begin{array}{l}\text { 'I want to reward myself after...' } \\
\text { 'When I have worked hard for something' }\end{array}$ \\
\hline Consolation & $\begin{array}{l}\text { 'In order to console myself' } \\
\text { 'If it feels grey and gloomy', }\end{array}$ \\
\hline Allowance & 'I gave myself the permission' \\
\hline Self-regard & 'I need to take care of myself' \\
\hline Indulgence & $\begin{array}{l}\text { 'I feel better' } \\
\text { 'Makes you feel great' }\end{array}$ \\
\hline Nostalgia & $\begin{array}{l}\text { 'My parents have lived [there; the place of origin } \\
\text { of the brand]' }\end{array}$ \\
\hline Celebration & $\begin{array}{l}\text { 'For my birthday' } \\
\text { 'When I retired' }\end{array}$ \\
\hline
\end{tabular}


Table 5: Motivations of self-gifting as means of social communication

\begin{tabular}{ll}
\hline Motivation & Participant response \\
\hline Impression & 'To dress to impress somebody' \\
Confidence & 'It makes you confident' \\
Credibility & 'To make what you are doing serious' \\
Belonging & 'Social acceptance \\
Approval & 'I have received feedback' \\
\hline
\end{tabular}

